\title{
Soil nutrients and salinity after long-term grazing exclusion in a Flooding Pampa grassland
}

\author{
ENRIQUE J. CHANETON AND RAUL S. LAVADO.
}

Authors are assistant research scientist, Department of Ecology; and associate professor, Department of Soils; Faculty of Agronomy, University of Buenos Aires, Av. San Martin 4453, 1417 Buenos Aires, Argentina.

\begin{abstract}
Soil organic $\mathbf{C}$, total $\mathbf{N}$, extractable $\mathbf{P}$, and salinity were evaluated after 12-16 years of protection from grazing in 2 native grassland sites which differed in frequency of soil waterlogging in the Flooding Pampa of Argentina. We tested the hypothesis that flooding regime would affect the impact of grazing on soil chemical properties. We sampled soil to $10-\mathrm{cm}$ depth in adjacent grazed and ungrazed plots in each site, and assessed the percentage dissimilarity (PD) in vegetation composition among pastures. Grazing condition significantly interacted with site $(\mathbf{P}<0.001)$ in affecting topsoil $\mathrm{C}, \mathrm{N}$, and salinity. Soil $\mathrm{C}$ and $\mathrm{N}$ were higher in grazed grassland $(C=4.8 \% ; N=0.42 \%)$ than in long-term exclosure $(C=3.7 \% ; N=0.35 \%)$ for the more frequently flooded, lowland site, but did not vary between grassland plots in the upland site $(C=3.1 \% ; N=0.29 \%)$. Soil electrical conductivity (E.C.) was low in both ungrazed plots $(<2 \mathrm{dS} / \mathrm{m})$, yet in grazed condition salinization was higher in the upland $(E . C .=6.85 \mathrm{dS} / \mathrm{m})$ than in the lowland site $(3.88 \mathrm{dS} / \mathrm{m})$. Soil extractable $P$ did not change in any consistent way with grazing treatment. Grazing apparently amplified differences in soil chemistry between lowland and upland sites, while differences in botanical composition between topographical positions were smaller for grazed (PD = $44 \%$ ) than for ungrazed (64\%) grassland. Moreover, contrasting responses between sites occurred for various soil parameters, whereas compositional differences between grazed and ungrazed plots were similar in each site $(P D \approx 65 \%)$. Thus, soil-vegetation changes in response to grazing appeared to be loosely coupled in this rangeland ecosystem.
\end{abstract}

Key Words: Argentina, landscape heterogeneity; nutrient cycling, plant community dynamics, soil organic matter, topography

The spatial heterogeneity of organic matter accumulation and soil chemical properties in grassland ecosystems is controlled by composite physical and biotic factors-including topography, soil microclimate, vegetation, and grazing, which change over different time scales (Jenny 1980; Burke 1989). Slowly changing factors, e.g. topography, constrain the variation of fast-response variables, such as soil water regime and plant composition. Large

Research was funded by grants from Consejo Nacional de Investigacione Científicas y Técnicas de Argentina (CONICET). E. Ch.aneton was partly supported by a CONICET extended fellowship. R.J.C. León and H. Trebino provided valuable discussion on an early draft of the manuscript.

Manuscript accepted 27 May 1995. herbivore grazing affect vegetation structure and composition, and hence the substrate and soil environment for microbial processes across landscape gradients (Seagle et al. 1992). Such interactions may be responsible for the varied effect that grazing seems to produce on soil carbon and mineral pools in grasslands (Milchunas and Lauenroth 1993).

The Flooding Pampa grasslands in southeastern South America (Soriano 1992) comprise a fine-grained mosaic of plant communities and soil types, most often associated with subtle differences in drainage regime (Batista et al. 1988; Burkart et al. 1990). Grazing by domestic livestock exerts strong, well-known influences on both structural (Sala et al. 1986; Facelli et al. 1989) and functional (Doll 1991; Chaneton et al. 1996) attributes of the natural grassland vegetation. In contrast, the role of grazing in shaping soil properties relevant to net primary production and nutrient turnover in pampean grasslands has not been well established, i.e., studied for a range of ecological conditions (see Smoliak et al. 1972; Marrs et al. 1989; Seagle et al. 1992).

Previous research in the central Flooding Pampa suggested that grazing has no measurable impact on carbon and mineral nutrient (N, P) pools in soils of less frequently flooded, upland grasslands (Lavado and Taboada 1985). Conversely, these studies indicated that continuous grazing may promote salinization of soil surface horizons, in connection with flood-drought cycles (Lavado and Taboada 1987, 1988). No attention has been paid to the interaction of grazing regime with topography in determining soil properties. Recurrent flooding is a prominent feature of this ecosystem (Sierra and Montecinos 1990), and topographic relief controls the spatial variation in frequency and duration of waterlogging events. Inter-site differences in soil drainage and aeration over seasonal/annual time scales may affect patterns of organic matter accumulation (Jenny 1980; Schimel et al. 1985a) and nutrient cycling (Ruess and Seagle 1994), in addition to salt movement within the soil (Lavado and Taboada 1987, 1988; Alconada et al. 1993). Therefore, grazing impact on grassland soil chemistry could vary across landscape positions.

The objective of this study was to evaluate the interactive influence of grazing and topography on selected parameters related to soil fertility in a Flooding Pampa rangeland. We hypothesized that site differences in soil waterlogging regime would modify the effects of livestock grazing on soil chemical properties. Here we report changes in soil organic carbon (C), total nitrogen (N), extractable phosphorus (P), and salinity, after about 15 years of protection from grazing in 2 stands of native grassland located at different topographical positions. Differences in plant community 
composition among pastures were examined as well, to address the potential relationship between changes in botanical structure and edaphic conditions. Total $\mathrm{C}$ and $\mathrm{N}$ pools, available $\mathrm{P}$, and $\mathrm{C} /$ nutrient ratios, were all considered soil variables indicative of longer-term system responses to management, whereas the degree of topsoil salinization would reflect short-term impacts of grazing (cf. Burke 1989).

\section{Methods}

\section{Study Area}

The study was conducted on a ranch located at the Río Salado basin in the center of the Flooding Pampa ( $\left.36^{\circ} 30^{\prime} \mathrm{S}, 58^{\circ} 30^{\prime} \mathrm{W}\right)$, eastern Buenos Aires province, Argentina (Soriano 1992). The area has been grazed for cattle production since the turn of the century. The climate is temperate subhumid, with mean monthly temperatures ranging from $8.2^{\circ} \mathrm{C}$ in July to $21.8^{\circ} \mathrm{C}$ in January, and a mean annual precipitation of $1,007 \mathrm{~mm}(1971-1990)$. The landscape is quite flat, with broad sandy ridges and slopes lower than $0.1 \%$ (Burkart et al. 1990). Dominant soils are loamy and slightly acidic at the surface and have a conspicuous B2t horizon at $25-50 \mathrm{~cm}$ depth. Surface runoff is negligible; water surpluses from winter-spring rainfall tend to accumulate in the lowlands causing soil waterlogging. In most years winter-spring flooding is followed by marked water deficits during the summer (Lavado and Taboada 1988; Sierra and Montecinos 1990). High watertable levels are usual and, together with the prevalent hydrologic regime, determine the halo-hydromorphic nature of most soils (Soriano 1992).

Natural grasslands are subjected to continuous livestock grazing on extensive paddocks. About half the vegetation cover is made up of forb species, which coexist with a diverse mixture of grasses and sedges. Protection from grazing dramatically changes the grassland structure and botanical composition. Aboveground green biomass and litter accumulate in exclosures (Sala et al. 1981; Hidalgo and Cauhépé 1991), while invasive dicots are soon replaced by native tall grasses (Sala et al. 1986; Facelli et al. 1989). Plant communities in the study area have been defined by broad surveys and mapped in relation to landscape position and soils (Burkart et al. 1990).

\section{Grassland Sites and Treatments}

We carried out the study on 2 sites which differ in annual soil waterlogging regime and dominant plant community. Grassland sites were located $6 \mathrm{~km}$ from each other at subtly different topographical positions, being separated by $\approx 20 \mathrm{~cm}$ in height. Soils of these sites were never plowed, having sinilar morphology (A1B1-B2-B3) and particle size distribution, but contrasting salinity profiles (Berasategui and Barberis 1982; Batista and León 1992). The "upland" soil was classified as Typic Natraquoll, and the "lowland" soil corresponds to a Typic Argiaquoll. The lowland site is affected almost every year by floods of greater depth and duration than those ocurring (less frequently) in the upland site (Berasategui and Barberis 1982; Burkart et al. 1990). Electrical conductivity may reach $10 \mathrm{dS} / \mathrm{m}$ in the upland soil, whereas it remains below $4 \mathrm{dS} / \mathrm{m}$ in the lowland one. In the nominal grazed condition, the upland plant community was characterized by the Piptochaetium montevidense (Spreng.) L.R. Parodi, Eclipta bellidioides (Spreng.) Sch.Bip., Ambrosia tenuifolia Spreng., Mentha pulegium L., and Briza subaristata Lam. association. The lowland community was described as a Mentha pulegium L., Leontodon taraxacoides (Vill.) Merat, and Paspalidium paludivagum (Hitchc. et Chase) Parodi plant association (Burkart et al. 1990).

In each site, 2 grazing treatments were maintained for the last 12-16 years in adjacent (paired) 2-ha plots delimited on formerly homogeneous prairie: (i) total livestock exclusion, from plots fenced in 1976 (upland site) and 1972 (lowland), and (ii) continuous grazing by cattle, which is the usual managerial practice in the system. Current grazing regime started in an undefined past, about a century ago; the annual average stocking rate was alike in both sites $(0.5 \mathrm{cow} / \mathrm{ha})$. These treatments were not replicated.

\section{Sampling and Data Analysis}

Twenty-five soil cores, $6 \mathrm{~cm}$ in diameter, were extracted to 10 $\mathrm{cm}$ depth from the A1 horizon in each of the 4 grassland sites, in midsummer 1989. Sampling was regularly done along transects, leaving $5 \mathrm{~m}$ between contiguous samples in an attempt to avoid spatial autocorrelation and reduce interdependence of observations (after Lavado et al. 1996). We omitted sampling 10m-wide strips each side of the fenceline that separated ungrazed from grazed plots in each pasture. Soil samples were air-dried and passed through a $2-\mathrm{mm}$ sieve prior to chemical analyses. Total organic $\mathrm{C}$ content was determined by the Walkley-Black method, total $\mathrm{N}$ by Kjeldahl digestion, and extractable $\mathrm{P}\left(\mathrm{P}_{\mathrm{i}}\right)$ by the BrayKurtz method, following procedures described in Page et al. (1982). Soil electrical conductivity (E.C.) was measured in saturation extracts and used to evaluate the degree of topsoil salinization. Bulk density data (core method) were available from Taboada and Lavado (1988), who reported almost no significant difference between grazed and ungrazed plots over a 33-month study; for present estimations, we used a mean bulk density value of 1.17 .

Plant community composition was described in each grassland plot as part of a long-term study. We measured species' basal cover in early summer by the line interception method, using four 5-m long transects on each plot. Data shown here are mean plant abundances $(+\mathrm{SD})$ for 3 consecutive years, including dry and wet years with precipitation 32 and $28 \%$ below and above the annual average, respectively. We calculated the percentage dissimilarity (PD) in species composition between paired plots at equal topographic position, and between plots under similar grazing treatment (lowland vs. upland), on a per-year basis, using the complement of Czekanowski's similarity index (Greig-Smith 1983, p. 151). Compositional similarities between plant communities were computed as $P S=\Sigma$ min $\left(a_{i}, b_{i}\right)$, where $a$ and $b$ represented relative basal cover of species " $i$ " on each site, being PD = PS - 100 .

Patterns in soil conditions were statistically examined by 2 -factor ANOVA for a split-plot design without replication, with the site (topographic position) as main block, and grazing treatments assigned to subunits (Steel and Torrie 1980). Cumulative normal probability plots were displayed to evaluate data normality. Variance homogeneity was examined through the $F_{\max }$ test (Sokal and Rohlf 1969). Accordingly, $P_{i}$ data were logarithmically transformed to correct for heterogeneous variances. Because E.C. variances were largely unequal $(\mathrm{P}<0.001)$ even after transformation, we performed an approximate F' test (Sokal and Rohlf 1969 , p. 372) on $\log (x+1)$-transformed data to address overall differences among plots in this parameter. Differences among pastures in soil properties were considered significant only when 
$P \leq 0.01$, in order to reduce the bias in using the sampling error to evaluate treatment effects (see Wester 1992). For soil parameters meeting ANOVA assumptions, Fisher's protected Least Significant Difference tests (L.S.D., $P<0.01$ ) were used to perform multiple comparisons of means. For soil E.C., selected pairwise comparisons were done by Welch's modified $t$ test, with $\mathrm{df}$ adjusted by the Satterthwaite method (Day and Quinn 1989). Means are reported in original scales.

Clearly, our design was pseudoreplicated for unambiguously estimating the effects of grazing and topographical position on soil conditions (Hurlbert 1984). Therefore, the implied level of statistical inference does not go beyond the 2-ha plots used in this study (Brown and Waller 1986; Wester 1992). Although design restricted the interpretation of results, it should be regarded that each exclosure was originally established on a levelled, homogeneous native pasture ( $R$. León, pers. comm.), classified into a given plant association according to the phytosociological method (Burkart et al. 1990). Also, vegetation and soils within and outside these exclosures were occasionally monitored in previous works (see Sala et al. 1986; Lavado and Taboada 1985, 1987; Chaneton et al. 1988, 1996). Our analysis then assumed that grazed and ungrazed plots were identical in both soil and vegetation at the outset, and that grazed plots did not follow any temporal trend in measured soil properties.

\section{Results}

\section{Soil Nutrients}

Soil organic $\mathrm{C}$ and total $\mathrm{N}$ were strongly correlated across all patches sampled in the 4 grassland plots $\left(r^{2}=0.90, P<0.001\right.$, $\mathrm{df}=98$ ). There was a highly significant interaction effect of grazing treatment and site on both $\mathrm{C}$ and $\mathrm{N}$ soil pools (Table 1). Topsoil $\mathrm{C}$ and $\mathrm{N}$ were significantly lower inside the exclosure than under continuous grazing in the lowland grassland site (Table 2), but did not differ between plots in the upland site. Plots located in the lowland site contained higher amounts of $\mathrm{C}$ and $\mathrm{N}$ in soil than their upland counterparts (Table 2). Organic $\mathrm{C}$ averaged $4,350-5,580 \mathrm{~g} / \mathrm{m}^{2}$ in lowland plots, and $\approx 3,600 \mathrm{~g} / \mathrm{m}^{2}$ in upland plots. Total soil $\mathrm{N}$ content ranged from about 328 to 490 $\mathrm{g} / \mathrm{m}^{2}$ in these plots. Soil $\mathrm{C} / \mathrm{N}$ ratios showed a slight, though statistically consistent (Table 1 ), pattern of variation among plots. Most obvious differences were due to the higher $C / N$ ratio of grazed, lowland soil (Table 2).

Extractable soil $P$ was loosely related to organic $C$ across grassland patches sampled within the study plots $\left(r^{2}=0.35, P<0.001\right.$, $\mathrm{df}=98$ ). At the plot level, we did not find significant differences

Table 1. Results of split-plot factorial ANOVA (F ratios) on average conditions of soil fertility in adjacent (paired) grazed and ungrazed plots, located in lowland and upland sites of native grassland. Sources of variation are for differences in inherent soil variability between situations. $d . f_{.}=1,48$ for all variance ratios.

\begin{tabular}{lccc}
\hline \hline & \multicolumn{3}{c}{ Source of Variation } \\
\cline { 2 - 4 } & Site & Plot & Site $\times$ Plot \\
\hline Organic C & $221.01^{* * * *}$ & $43.37^{* * *}$ & $49.72^{* * * * *}$ \\
Total N & $157.16^{* * * *}$ & $14.47^{* * *}$ & $33.18^{* * * *}$ \\
C/N & $17.49^{* * *}$ & $18.55^{* * *}$ & $2.40^{\mathrm{NS}}$ \\
Extr. $P_{\mathrm{i}}$ & $45.30^{* * *}$ & $0.29^{\mathrm{NS}}$ & $6.29^{\mathrm{NS}}$ \\
C/P & $0.24^{\mathrm{NS}}$ & $4.48^{\mathrm{NS}}$ & $0.01^{\mathrm{NS}}$ \\
\hline
\end{tabular}

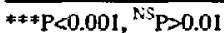

in soil $\mathrm{P}_{\mathrm{i}}$ between grazing treatments, but average $\mathrm{P}_{\mathrm{i}}$ concentration consistently increased from the upland to the lowland grassland (Tables 1,2 ). In all, measured levels of soil $P_{i}$ were always relatively low (all-samples median $=5.2 \mathrm{mg} / \mathrm{kg}$ ). The $\mathrm{C} / \mathrm{P}_{\mathrm{i}}$ ratio showed no significant change with landscape position or grazing treatment, although it tended to be higher in grazed plots (Table 2).

\section{Soil Salinity}

Analysis of variance of E.C. patterns indicated that there were overall significant differences among plots in soil salinity $(F=154.09, \mathrm{P}<0.001, \mathrm{df}=3,30)$. Soil E.C. was remarkably lower $(\mathrm{P}<0.001$, Welch's $t)$ within long-term grazing exclosures, for both upland and lowland grassland sites (Table 2). Higher average levels of topsoil salinization $(\mathrm{P}<0.001)$ under continuous grazing were found in the upland (range $=3.7-13.6 \mathrm{dS} / \mathrm{m}$ ) than in the lowland site (2.2-6.3 dS/m) (see Table 2).

\section{Plant Community Composition}

Prolonged exclusion of cattle dramatically reduced the coolseason forb cover (Table 3). Grasses dominated within exclosures of both upland and lowland grassland. Warm-season grass species strongly dominated plots of lowland grassland, whereas cool-season grasses increased 4-fold and became dominant with protection from grazing in the upland site (Table 3). Grazed and ungrazed plots nevertheless differed in overall plant species composition similarly for upland and lowland sites (mean annual PD $=62-68 \%$ ). Yet, plant communities in exclosures located at different topographical position showed greater annual dissimilarity (mean $\mathrm{PD}=63.6 \%$ ) than their counterparts under continuous grazing ( $P D=43.8 \%)$.

\section{Discussion}

Soil organic $\mathrm{C}$ and total $\mathrm{N}$ were highest in lowland, grazed grassland (Table 2). Increased organic matter content in downslope positions and swales has been shown in various ecosystems (e.g. Schimel et al. 1985a; Burke 1989), being often attributed to the physical transport of materials downward. This process would seldom be operative in the study area given the gentle slope and flatness of land forms, yet some export of dissolved nutrients from upland to lowland sites might occur upon flooding. In addition, accumulation of $C$ and mineral nutrients in lowlands would reflect landscape differences in local turnover of elements associated with varying decomposition rates. Severe anaerobiosis induced by prolonged floods reduces the activity of soil microorganisms (Ponnamperuma 1984), decreasing $C$ outputs through microbial respiration from lowland soils (Schimel et al. 1985b). Nitrogen pools of frequently waterlogged soils may also reflect changes in microbial processes leading to low net mineralization rates, as well as increased denitrification (Ponnamperuma 1984). Moreover, there is a potential for higher plant productivity in lowland sites, and hence for greater $\mathrm{C}$ inputs to soil (Schimel et al. 1985a; Milchunas and Lauenroth 1989), but we have no data to test this hypothesis in the studied ecosystem.

The significantly lower amount of $C$ and $N$ measured in the lowland soil under exclosure conditions (Table 2) apparently reflected a major change in the pattern of element cycling, which resulted in large quantities of $\mathrm{C}$ and $\mathrm{N}$ flowing through the above- 
Table 2. Soil parameters (mean \pm SE) in continuously grazed pastures and adjacent exclosures (12-16 year-old) of native Flooding Pampa grassland, in sites subjected to contrasting flooding regime. Values are for 25 replicate samples (10cm deep), except for electrical conductivity (E.C., $n=16)$. Different letters in a row indicate means are significantly different $(P<0.01)$. Log-transformed SEs are shown for $P_{i}$ and $E$.C.

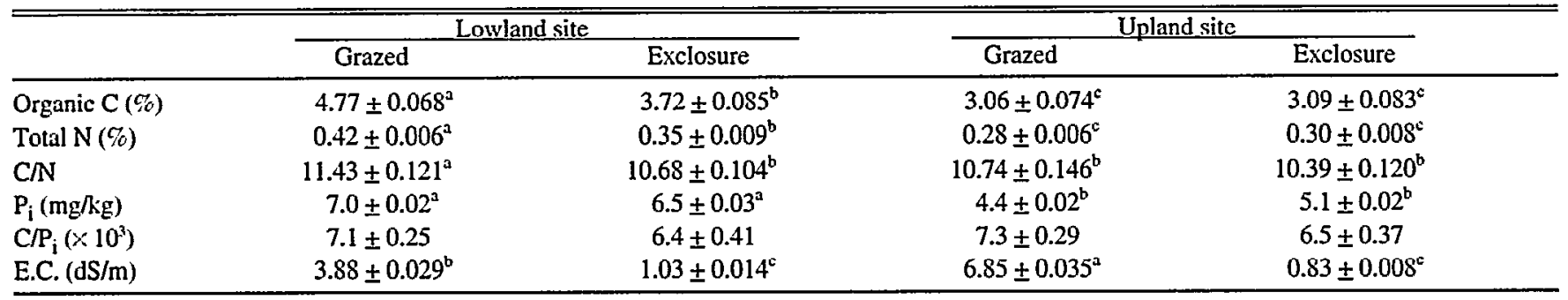

ground vegetation pathway in absence of domestic herbivores (Sala et al. 1981; Chaneton et al. 1996). This result agrees with those of some authors (Kelting 1954; Smoliak et al. 1972; Dormaar et al. 1994), but contrasts with decreases in organic matter and/or total $\mathrm{N}$ content produced by grazing elsewhere (Johnston et al. 1971; Marrs et al. 1989; see for a review, Milchunas and Lauenroth 1993). In mesic grasslands, large amounts of plant material accumulate onto the soil surface in ungrazed areas (Kelting 1954; Knapp and Seastedt 1984), while belowground productivity often decreases (e.g. Doll 1991). Carbon and nutrients captured by vegetation may then become trapped in a thick litter layer that slowly decomposes by the action of fungal microflora (Knapp and Seastedt 1984; Holland and Coleman 1987). In contrast, a more rapid transfer of elements to soil pools is generally promoted under continuous grazing, with less nutrient retained in aboveground vegetation (Chaneton et al. 1996).

Previous studies in these grasslands showed that belowground decomposition rates were higher within exclosures than in grazed plots (Landaburu 1982; Sanchez 1987). Here, $C / N$ and $C / P_{i}$ ratios tended to be higher under grazing, suggesting that soil microbes would be more limited by nutrients than by substrate (C) availability in that situation (Ruess and McNaughton 1987; Seagle et al. 1992), particularly in lowland grasslands (Table 2). In the case of Flooding Pampa, soil microbial activity seems to be facilitated by the improved aeration (less compaction; Taboada and Lavado 1988) and higher moisture content of soil under long-term protection from grazing (Lavado and Taboada 1987; Sanchez 1987).

We found contrasting soil responses between lowland and upland sites, although changes in whole phytomass structure after grazing exclusion are similar in both, as shown by Sala et al. (1986). Particular responses may occur because of initial (site) differences in soil conditions under sustained grazing. However, with cattle exclusion, plant communities at different topographical positions exhibited alternative replacement of forbs by distinct functional groups of grasses (Table 3). Thus, we speculate that differences in $\mathrm{C}$ and $\mathrm{N}$ turnover between landscape positions probably reflect differences in the quality of plant material available to decomposers (Seagle at al. 1992). In ungrazed, upland sites, the remarkably higher biomass of cool-season $\left(\mathrm{C}_{3}\right)$ grasses (Sala et al. 1981, 1986) might accelerate element cycling through a lower C/N ratio of surface litter (Hobbie 1992), precluding substantial sequestration of nutrients in aboveground plant compartments, and changes in soil fertility from grazed to ungrazed situations.

Contrary to patterns observed for $C$ and $N$ pools, soil $P_{i}$ did not change with grazing treatment, which supported previous findings in this system (Lavado and Taboada 1985; Chaneton et al. 1996). A similar result was found in mixed-prairie sites (Smoliak et al. 1972), although extractable $P$ was also variously reported to decrease or increase with grazing (Johnston et al. 1971; Marrs et al. 1989). Present results concurred with the minor impact that livestock grazing had on the $\mathrm{P}$ budget, compared to that on $\mathrm{N}$ cycling, in an upland Flooding Pampa grassland (Chaneton et al. 1996). Higher $P$ returns to soil through animal excreta in grazed sites (Ruess and McNaughton 1987) would be compensated by enhanced rates of nutrient uptake by vegetation, which together determined fast rates of $P$ cycling (Chaneton et al. 1996). Nevertheless, $P_{i}$ levels were rather low in all 4 study plots, supporting the notion that plant productivity in these rangelands would be primarily limited by P supply, as indicated by fertilization experiments (e.g. Ginzo et al. 1982; Rubio et al. 1995).

We found consistently higher topsoil salinity levels in grazed than in ungrazed grassland plots. Interestingly, soil E.C. was low in both exclosures (Table 2). Although such a grazing effect had been previously noted in upland Natraquolls (Lavado and

Table 3. Abundance of plant functional groups in continuously grazed plots and in long-term grazing exclosures in the Flooding Pampa, Argentina, shown by their mean (SD) basal live cover in early summer for 3 consecutive years (16-19 Jan. 1989-91).

\begin{tabular}{|c|c|c|c|c|}
\hline & \multicolumn{2}{|c|}{ Lowland site } & \multicolumn{2}{|c|}{ Upland site } \\
\hline & Grazed & Exclosure & Grazed & Exclosure \\
\hline & & 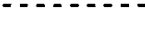 & & $=--$ \\
\hline $\begin{array}{l}\text { Grasses } \\
\text { Warm-season } \\
\text { Cool-season }\end{array}$ & $\begin{array}{r}15.7(2.4) \\
6.2(6.4)\end{array}$ & $\begin{array}{r}14.9(2.4) \\
2.0(1.9)\end{array}$ & $\begin{array}{r}15.3(3.1) \\
3.5(2.3)\end{array}$ & $\begin{array}{l}12.8(1.7) \\
14.5(6.3)\end{array}$ \\
\hline $\begin{array}{l}\text { Forbs } \\
\text { Warm-season } \\
\text { Cool-season }\end{array}$ & $\begin{array}{r}0.8(0.6) \\
10.7(4.7)\end{array}$ & $\begin{array}{l}2.8(2.6) \\
0.9(0.7)\end{array}$ & $\begin{array}{l}1.2(1.1) \\
9.4(2.5)\end{array}$ & $\begin{array}{l}2.0(1.2) \\
0.1(0.1)\end{array}$ \\
\hline
\end{tabular}


Taboada 1987) and in Natraqualfs (Lavado et al. 1992), here it was recorded for the first time in a lowland, non-alkaline soil. Continuous grazing increases salt content by reducing aerial plant and litter cover, which lead to higher soil temperatures and evaporation rates (Lavado and Taboada 1987). Salinization occurs as pulses in late spring and early summer, and is facilitated by a shallow and saline water table. Salts move upward from deep horizons through the $B 2 t$ and reach the soil surface in periods of high atmospheric demand (Lavado and Taboada 1987, 1988; Lavado et al. 1992). Topsoil salinization peaks are followed by salt leaching caused by rainfall and soil waterlogging events (Lavado and Taboada 1988; Alconada et al. 1993). We observed, however, that soil salinity in grazed areas varied substantially with landscape position (see Table 2). Less accumulation of soluble salts (and general lack of halomorphic features) in the lowland soil probably resulted from the overriding hydrologic regime associated with frequent and prolonged flooding (Berasategui and Barberis 1982; Alconada et al. 1993).

The interactive influence of topography and grazing on topsoil $\mathrm{C}, \mathrm{N}$, and salinity suggests that there existed considerable landscape heterogeneity in soil responses to management (cf. Schimel et al. 1985b). Variation across topographical positions most probably reflected the impact of contrasting waterlogging regimes on process dynamics at the soil-plant interface. Caution should be taken, however, in interpreting differences observed between adjacent grassland plots as produced only by grazing exclusion. Drawing from knowledge on the initial homogeneity of studied pastures, we could confidently assume that differences did not occur because of existing spatially correlated patterns in soil properties. In fact, Lavado et al. (1996) showed that the spatial dependence (semi-variance) of various chemical parameters in these soils leveled off at much smaller scales than those inherent to present plot comparisons. On the other hand, it is not possible to assure that results were not affected by some unrecognized trend, e.g., in soil $\mathrm{C}$ and $\mathrm{N}$, under continuous grazing (see lowland in Table 2). But no directional change was apparent in stocking rate, pasture composition (E.J. Chaneton, unpubl. data), or climate conditions (Sierra and Montecinos 1990) over the last 2 decades. If plot differences detected in lowland grassland were caused by the exclosure treatment, an average of $5 \mathrm{gN} \mathrm{m}^{-2} \mathrm{yt}^{-1}$ would have been lost from the soil over a 16 -yr period, an amount that compares reasonably well with the $15 \mathrm{gN} \mathrm{m}^{-2}$ estimated for total annual uptake, and $\approx 2 \mathrm{~g} / \mathrm{m}^{2}$ more $N$ located in aboveground vegetation inside than outside a 7-yr-old exclosure (Chaneton et al. 1996).

Sustained livestock grazing appeared to amplify intrinsic differences in soil nutrient content and salinity between topographical positions (Table 1,2), whereas long-term exclusion increased differences in plant species composition (PD) and relative abundance of functional groups (Table 3 ) between sites. Sala et al. (1986) found similar vegetation patterns using seasonal data from nearby 4-year-old exclosures and grazed pastures. Grazing reduced the spatial heterogeneity of grassland vegetation through the generalized invasion of herbaceous dicots (Table 3 ) and the suppression of bunch grasses (Sala et al. 1986; Facelli et al. 1989). These findings are summarized in a conceptual model presented in Figure 1. We point out that colonization of grazed sites by forbs and non-forage grass species may happen independently of site-specific changes in soil properties. The model suggests that grazing interferes with the control exerted by topography and soil on community composition (see also Sala et al. 1986), while

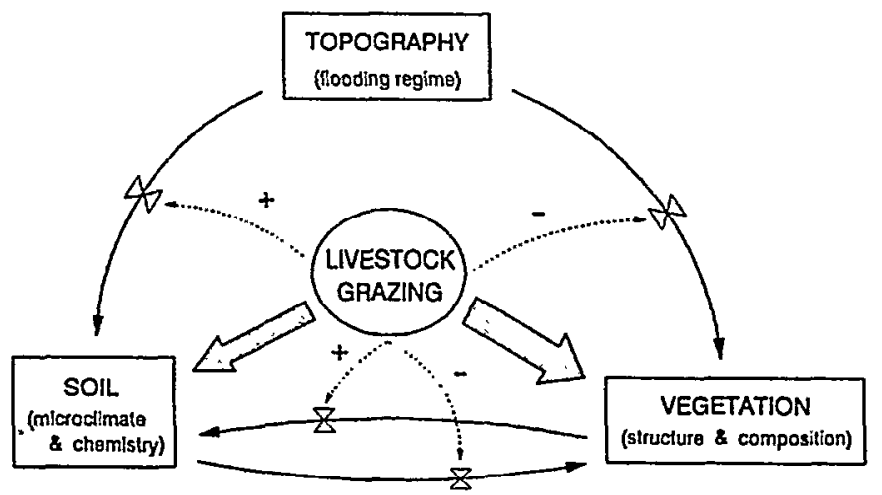

Fig. 1. Conceptual model of the interactive effect of grazing on soil and vegetation in central Flooding Pampa grasslands. Arrows denote the relative strength of direct grazing effects. Solid lines show the direct influence of one factor on another; dashed lines depict indirect grazing influence on the relationship between other ecosystem components. Signs indicate synergistic (+) or inhibitory $(-)$ control on soil/vegetation heterogeneity across the landscape (as suggested by data; see text). Feed-backs to grazing omitted for simplicity.

the grazing-topography interaction sinergistically affects soil heterogeneity (Fig. 1). Therefore, vegetation dynamics in response to management (Hidalgo and Cauhépe 1991), or natural disturbance (Chaneton et al. 1988), would be partially decoupled from habitat parameters sensible to ecosystem function.

In an extensive compilation on grazing effects across ecosystems, Milchunas and Lauenroth (1993) obtained no clear relationship between the difference in species composition of grazed vs. ungrazed sites and the relative impact of grazing on soil organic matter (or $\mathrm{C}$ ) and $\mathrm{N}$ pools. They suggest this resulted from the different response time of vegetation and soil variables. In this study we show that, for a given degree of compositional dissimilarity between grazing treatments $(\approx 65 \%)$, there were either significant differences $(20-28 \%)$ or almost no change (1-5\%) in soil $\mathrm{C}$ and $\mathrm{N}$, depending on the landscape position (see also Marrs et al. 1989). We conclude that local site factors (e.g., topography; waterlogging regime) affect ecosystem responses to grazing, partly explaining the lack of consistency in broad-scale response patterns.

\section{Literature Cited}

Alconada, M., O.E. Ansín, R.S. Lavado, V.A. Deregibus, G. Rubio, and F.H. Gutierrez Boem. 1993. Effect of retention of run-off water and grazing on soil and on vegetation of a temperate humid grassland. Agri. Water Manage. 23:233-246.

Batista, W.B. and R.J.C. León. 1992. Asociación entre comunidades vegetales y algunas propiedades del suelo en el centro de la Depresión del Salado. Ecol. Austral 2:47-55.

Batista, W.B., R.J.C. León, and S.B. Perelman. 1988. Las comunidades vegetales de un pastizal natural de la región de Laprida, Prov. de Buenos Aires, Argentina. Phytocoenologia 16:465-480.

Berasategui, L.A. and L.A. Barberis. 1982. Los suelos de las comunidades vegetales de la región Castelli-Pila, Depresión del Salado (Pcia. de Buenos Aires). Rev. Fac. Agron., Bucnos Aircs 3:13-25.

Brown, M.A. and S.S. Waller. 1986. The impact of experimental design on the application of grazing research results-an exposition. J. Range Manage. 39:197-199. 
Burkart, S.E., R.J.C. León, and C.P. Movia. 1990. Inventario fitosociológico del pastizal de la Depresión del Salado (Pcia. de Buenos Aires) en un area representativa de sus principales ambientes. Darwiniana 30:27-69.

Burke, I.C. 1989. Control of nitrogen mineralization in a sagebrush steppe landscape. Ecol. 70:1115-1126.

Chaneton, E.J., J.M. Facelli, and R.J.C. León. 1988. Floristic changes induced by flooding on grazed and ungrazed lowland grasslands in Argentina. J. Range Manage. 41:495-499.

Chaneton, E.J., J.H. Lemcoff, and R.S. Lavado. 1996. Nitrogen and phosphorus cycling in grazed and ungrazed plots in a temperate subhumid grassland in Argentina. J. Appl. Ecol. (in press).

Day, R.W. and G.P. Quinn. 1989. Comparisons of treatments after an analysis of variance in ecology. Ecol. Monogr. 59:433-463.

Doll, U.M. 1991. C-14 translocation to the belowground subsystem in a temperate humid grassland (Argentina), p. 350-358. In: B.L. McMichael, and H. Persson (eds), Plant roots and their environment. Elsevier Science Pub., Amsterdam.

Dormaar, J.F., B.W. Adams, and W.D. Willms. 1994. Effect of grazing and abandoned cultivation on a Stipa-Bouteloua community. $J$. Range Manage. 47:28-32.

Facelli, J.M., R.J.C. León, and V.A. Deregibus. 1989. Community structure in grazed and ungrazed grassland sites in the Flooding Pampa, Argentina. Am. Midl. Nat. 121:125-133.

Ginzo, H.D., M.B. Collantes, and O.H. Caso. 1982. Fertilization of a native grassland in the 'Depresion del Salado', Province of Buenos Aires: herbage dry matter accumulation and botanical composition. J. Range Manage. 35:35-42.

Greig-Smith, P. 1983. Quantitative plant ecology, 3rd. ed. University of Califomia Press, Berkeley, Calif.

Hidalgo, L.G. and M.A. Cauhépé. 1991. Effects of seasonal rest on aboveground biomass for a native grassland of the Flooding Pampa, Argentina. J. Range Manage. 44:471-474.

Hobbie, S.E. 1992. Effects of plant species on nutrient cycling. Trend Ecol. Evol. 7:336-339.

Holland, E.A. and D.C. Coleman. 1987. Litter placement effects on microbial and organic matter dynamics in an agroecosystem. Ecology $68: 425-433$.

Hurlbert, S.H. 1984. Pseudoreplication and the design of ecological field experiments. Ecol. Monogr. 54:187-211.

Jenny, H. 1980. The soil resource. Springer-Verlag, N.Y.

Johnston, A., J.F. Dormaar, and S. Smoliak. 1971. Long-term grazing effect on fescue grassland soils. J. Range Manage. 24:185-188.

Kelting, R.W. 1954. Effects of moderate grazing on the composititon and plant production of a native tall-grass prairie in central Oklahoma. Ecol. 35:200-207.

Knapp, A.K. and T.R. Seastedt. 1984. Detritus accumulation limits productivity of tallgrass prairie. BioScience 36:662-668.

Landaburu, A.C. 1982. Descomposición de celulosa en un pastizal natural de la Depresión del Salado. Rev. Fac. Agron., Buenos Aires 3:51-55.

Lavado, R.S. and M.A. Taboada. 1985. Influencia del pastoreo sobre algunas propiedades químicas de un natracuol de la Pampa Deprimida. Ciencia del Suelo 3:102-108.

Lavado, R.S. and M.A. Taboada. 1987. Soil salinization as an effect of grazing in a native grassland soil in the Flooding Pampa of Argentina. Soil Use Manage. 3:143-148.

Layado, R.S., and M.A. Taboada. 1988. Water, salt and sodium dynamics in a natraquoll in Argentina. Catena 15:577-594.

Lavado, R.S., G. Rubio, and M. Alconada. 1992. Grazing management and soil salinization in two pampean natraqualfs. Turrialba 42:500-508.

Lavado, R.S., J.O. Sierra, and P.N. Hashimoto. 1996. Impact of grazing on levels and spatial variability of soil carbon, nitrogen and extractable phosphorus in a pampean grassland of Argentina. J. Range Manage. (in press)

Marrs, R.H., A. Rizand, and A.F. Harrison. 1989. The effects of removing sheep grazing on soil chemistry, above-ground nutrient distribution, and selected aspects of soil fertility in log-term experiments at Moor House National Nature Reserve. J. Appl. Ecol. 26:647-661.

Milchunas, D.G., and W.K. Lauenroth. 1989. Three-dimensional distribution of plant biomass in relation to grazing and topography in the shortgrass steppe. Oikos 55:82-86.
Milchunas, D.G. and W.K. Lauenroth. 1993. Quantitative effects of grazing on vegetation and soils over a global range of environments. Ecol. Monogr. 63:327-366.

Page, A.L., R.H. Miller, and D.R. Keeney (eds). 1982. Methods of soil analysis. Part 2. Chemical and microbiological properties. Amer. Soc. of Agron., Madison, Wisc.

Ponnamperuma, F.N. 1984. Effects of flooding on soils, p. 10-45. In: T.T. Kozlowski (ed), Flooding and plant growth. Academic Press, N.Y.

Rubio, G., G. Casasola, and R.S. Lavado. 1995. Adaptations and biomass production of two grasses in response to waterlogging and soil nutrient enrichment. Oecologia 102:102-105.

Ruess, R.W. and S.J. McNaughton. 1987. Grazing and the dynamics of nutrient and energy regulated microbial processes in the Serengeti grasslands. Oikos 49:101-110.

Ruess, R.W., and S.W. Seagle. 1994. Landscape patterns in soil microbial processes in the Serengeti National Park, Tanzania. Ecol. 75:892-904.

Sala, O.E., V.A. Deregibus, T. Schlichter, and H. Alippe. 1981. Productivity dynamics of a native temperate grassland in Argentina. J. Range Manage. 34:48-51.

Sala, O.E., M. Oesterheld, R.J.C. León, and A. Soriano. 1986. Grazing effects upon plant community structure in subhumid grasslands of Argentina. Vegetatio 67:27-32.

Sanchez, C.P. 1987. Descomposición fúngica de la celulosa en un pastizal de la Pampa Deprimida. Ciencia del Suelo 5:135-141.

Schimel, D., M.A. Stillwell, and R.G. Woodmansee. 1985a. Biogeochemistry of $\mathrm{C}, \mathrm{N}$, and $\mathrm{P}$ in a soil catena of the shortgrass steppe. Ecol. 66:276-282

Schimel, D.S., D.C. Coleman, and K.A. Horton. 1985b. Soil organic matter dynamics in paired rangelands and cropland toposequences in North Dakota. Geoderma 36:201-214.

Seagle, S.W., S.J. McNaughton, and R.W. Ruess. 1992. Simulated effects of grazing on soil nitrogen and mineralization in contrasting Serengeti grasslands. Ecol. 73:1105-1123.

Sierra, E.M. and E.R. Montecinos. 1990. Cronología de inundaciones y sequías en la Depresión del Salado. Rev. Fac. Agron., Buenos Aires 11:35-45.

Smoliak, S., J.F. Dormaar, and A. Johnston. 1972. Long-term grazing effects on Stipa-Bouteloua prairie soils. J. Range Manage. 25:246-250.

Sokal, R.R., and F.J. Rohlf. 1969. Biometry, 2nd. ed. Freeman Co. San Francisco, Calif.

Soriano, A. 1992. Río de la Plata grasslands, p. 367-407. In: R.T. Coupland (ed), Natural grasslands: introduction and westem hemisphere. Ecosystems of the World 8A. Elsevier, Amsterdam.

Steel, R.G.D. and J.H. Torrie. 1980. Principles and procedures of statistics: a biometrical approach, 2nd. ed.. McGraw-Hill, Tokyo

Taboada, M.A. and R.S. Lavado. 1988. Grazing effects on the bulk density in a natraquoll of the Flooding Pampa of Argentina. J. Range Manage. 41:500-503.

Wester, D.B. 1992. Viewpoint: replication, randomization, and statistics in range research. J. Range Manage. 45:285-290. 